\title{
Study on impact of feeding soyaladoo and soyaflakes chiwada to malnourished pre-school children and their biochemical analysis
}

Author for Correspondence :

\section{N.S. GHATGE}

Pravara Rural Education Society's, Home Science and BCA College, Loni, Rahata, AHMEDNAGAR (M.S.) INDIA

Email : nalinihemangi26@ rediffmail.com
DABSTRACT : To prevent malnutrition among children in the country in a sustainable manner are a critical component in this endeavor. This would require a multipronged effected in the form of capacity building for nutritional research, programme intervention development and evaluation. To treat malnutrition among the preschool children the formulation of locally based protein rich product is done. Hence attempt was made to formulate soyabased food products such as soyaladoo and soyaflakes chiwada. Soya products were formulated and prepared by standard methods. Organoleptically selected soya products were analyzed for its chemical composition such as protein, fat, vitamins, minerals, and ant nutritional factors. These products were supplemented to pre-school malnourished children @ $40 \mathrm{~g} / \mathrm{head} /$ day for six months. Preschool malnourished children were graded according to grade of malnutrition. Their biochemical parameter such as serum iron $(\mu \mathrm{g} / \mathrm{dl})$ serum proteins $(\mathrm{gl} / \mathrm{dl})$, serum vitamin $\mathrm{A}(\mathrm{IO} / \mathrm{dl})$, serum zinc ( $\mu \mathrm{g} \mathrm{ml}$ ), blood glucose $\mathrm{mg} / \mathrm{dl}$ and Haemoglobin $\mathrm{g} / \mathrm{dl}$ had done monthly for six months. It had shown highly significant changes on blood glucose level, haemoglobin, serum protein, serum vitamin A, serum iron and serum zinc states of pre-school children after supplementation of soyaproducts.

KEY WORDS: Soyladoo, Soyaflakes chiwada, Supplementary feeding

- HOW TO CITE THIS PAPER : Ghatge, N.S. (2015). Study on impact of feeding soyaladoo and soyaflakes chiwada to malnourished pre-school children and their biochemical analysis. Asian J. Home Sci., 10 (2) : 322-326. 